\title{
MIR206 wt Allele
}

National Cancer Institute

\section{Source}

National Cancer Institute. MIR206 wt Allele. NCI Thesaurus. Code C82163.

The human MIR206 wild-type allele is located in the vicinity of 6p12.2 and is approximately 85 bases in length. This allele, which encodes MIR206 pre-miRNA, plays a role in the regulation of gene expression. Alteration in the expression of this gene is associated with development of breast cancer and schizophrenia. 